\title{
Lifetime Simulation of Rechargeable Batteries for Solar powered Fishing Lights
}

\author{
Gunther Bohn ${ }^{1, a^{*}}$, Sven Bayer ${ }^{2, b}$, M. Stolz ${ }^{3 c}$, Ansgar Ackva ${ }^{1 d}$ \\ and Bernhard Arndt ${ }^{1, e}$
}

${ }^{1}$ Faculty of Electrical Engineering, University of Applied Sciences Würzburg/Schweinfurt, 97421 Schweinfurt, Germany

\author{
${ }^{2}$ Technologie-Transfer-Zentrum-Elektromobilität, University of Applied Sciences \\ Würzburg/Schweinfurt, 97616 Bad Neustadt, Germany \\ ${ }^{3}$ M.W.A.N.Z.A Assoziation, Unterdürrbacher Str. 346, 97080 Würzburg, Germany \\ a'Gunther.Bohn@fhws.de, ${ }^{b}$ Sven.Bayer@fhws.de, ${ }^{\mathrm{C}} \mathrm{m}$ _stolz@web.de, ${ }^{\mathrm{d} A n s g a r . A c k v a @ f h w s . d e ~}$ \\ eBernhard.Arndt@fhws.de \\ ${ }^{*}$ Corresponding Author
}

Keywords: Solar Energy, Battery, Simulation, Fishing

\begin{abstract}
In the developing world artisanal fishermen use kerosene lanterns for night fishing. Solar powered fishing lights became an ecologic and economic alternative to the kerosene lanterns due to the development of high efficiency LED light sources and low price solar cells. In the last years several solar fishing light systems were developed. The choice of the battery technology influences the reliability and the operating cost of the fishing light, because the battery has the lowest lifetime of all components of the fishing light.

In this paper we describe the results of a battery simulation over 5 years time: The battery is daily charged by a solar module and discharged by night fishing. The meteorological irradiation data of Tanzania are used. Different battery technologies (Lead Acid, Lithium-Ion, Lithium-IronPhosphate) are tried out.

The results of the simulation are the battery lifetime, cost and waste mass per year dependent on the battery technology. The study shows, that the Lithium-Iron-Phosphate technology is the best choice in terms of these factors and to the advantage of the poverty-stricken fishermen at the Victoria Lake in Tanzania and the environment.
\end{abstract}

\section{Introduction}

At night all over the world fishermen use lights to catch small fish [1]: Small fish live near the surface, move in schools and feed on zooplankton. Zooplankton is attracted by light. The small fish follow and can be caught by fishing nets.

Artisanal fishermen in developing countries use pressurized kerosene lanterns because of their high luminous flow. The drawbacks are high costs for the fishermen and $\mathrm{CO}_{2}$ emissions. In Tanzania for example 100000 night fishermen are working [1]. Each lantern has consumption between 1 and 21 of fuel per night of fishing. These fishermen are spending between $35 \%$ and $50 \%$ of their income on the kerosene lanterns and fuel. The annual $\mathrm{CO}_{2}$ emissions caused by night fishing in Tanzania are 84700 metric tons.

Prototypes of solar powered LED fishing lights were developed and successfully tested at different locations in Tanzania [1], [2]. The fishing light consists of the LED, an external solar module, a rechargeable battery and electronic components like a LED-driver and a battery charge controller. The battery is charged during the daytime by the external solar module. During the fishing night the battery supplies the LED light. It is estimated [3], that the lifecycle cost of a SolarLED fishing light is one-tenth that of the baseline kerosene strategy. 2013 the University of Applied Sciences Würzburg-Schweinfurt supplied a LED-light source. It was successfully tested by fishermen at the Lake Viktoria under the guidance of the Tanzania Renewable Energy Association 
Executive Secretary, J. Ruhonyora. In 2014 the first commercial solar powered LED fishing light source was brought on the market by OmniVoltaic [4].

The rechargeable battery is the weakest part of the electrical system: The solar module has a lifespan in the range of 20 years. The LED has an operation time in the range of 100.000 hours (12 years). The lifetime of the rechargeable battery is mostly limited by the cycle life. A typical Lithium-Ion battery can be only 300-500 times fully charged and discharged until its capacity drops to $70 \%$.

\section{Materials and Methods}

Input Data. We simulated the battery used in fishing lights at the Victoria Lake in Tanzania because the behavior of the fishermen at this location is well known: The fishing time is between 8 and 12 hours per day at 14 to 21 nights per month [1]. Further on we assumed that there is no fishing at full moon because of the increased irradiation during the night. The climate data were generated by the Meteonorm Software, which used the data of the meteorological station in Mwanza at the Victoria Lake.

Block Diagram. The simulated fishing light consists of the solar module, the charge controller, the battery pack, the current source supplying the LED and the LED itself (Fig. 1).

We assumed, that the luminous flux value $\Phi$ of the LED is $3001 \mathrm{~m}$ and that the peak power value of the solar module is $12 \mathrm{Wp}$. These values were found in the commercial product [1]. We also assumed, that the electrical efficiency $\eta_{\mathrm{el}}$ of the charge controller and the current source is $80 \%$, which is state of the art. The LED conversion efficiency

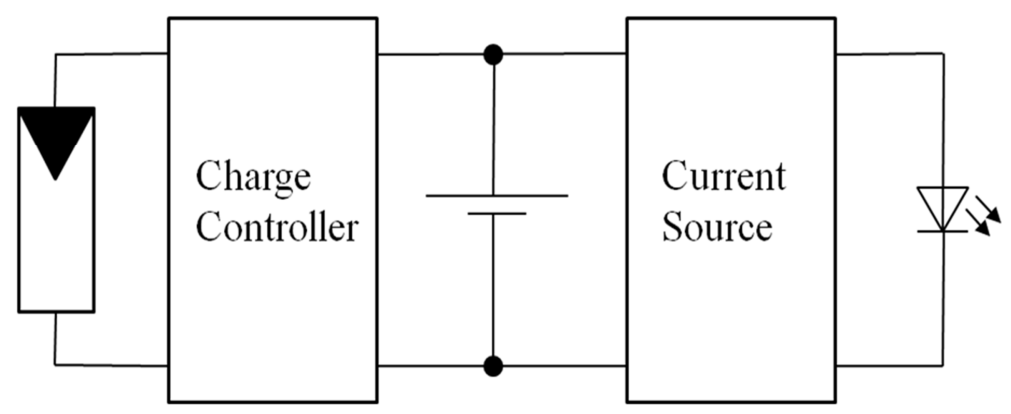

Figure 1: Block diagram of the simulated fishing light $\eta_{\text {LED }}$ is assumed $160 \mathrm{~lm} / \mathrm{W}$.

Table 1: Battery technology, cell type and battery pack

\begin{tabular}{|c|c|c|c|}
\hline Battery technology & Lithium-Ion & $\begin{array}{l}\text { Lithium-Iron- } \\
\text { Phosphate }\end{array}$ & Sealed Lead-Acid \\
\hline Nominal voltage $U_{N}[V]$ & 3.7 & 3.3 & 12 \\
\hline Cell type & $\begin{array}{l}\text { Samsung } \\
\text { ICR18650-26F }\end{array}$ & $\begin{array}{l}\text { A123 } \\
\text { ANR26650M1-B }\end{array}$ & $\begin{array}{l}\text { Multipower } \\
\text { MP5-12C }\end{array}$ \\
\hline Cell capacity $[\mathrm{Ah}]$ & 2.6 & 2.4 & 5 \\
\hline Cell serial resistor $[\mathrm{m} \Omega]$ & 100 & 9 & 18 \\
\hline Cycle life & $\begin{array}{l}\text { After } 299 \text { cycles } \\
\text { with } 100 \% \text { DoD } \\
70 \% \text { capacity }\end{array}$ & $\begin{array}{l}\text { After } 1000 \text { cycles } \\
\text { with } 100 \% \text { DoD } \\
95 \% \text { capacity }\end{array}$ & $\begin{array}{l}\text { After } 300 \text { cycles } \\
\text { with } 100 \% \text { DoD } \\
60 \% \text { capacity }\end{array}$ \\
\hline Coulombic efficiency [\%] & 100 & 100 & 90 \\
\hline $\begin{array}{l}\text { Battery pack } \\
\text { configuration }\end{array}$ & $4 p$ (parallel) & $5 p$ & $1 \mathrm{p}$ \\
\hline $\begin{array}{l}\text { Battery pack price [€] } \\
\left.\text { (June } 6^{\text {th }}, 2015\right)\end{array}$ & $\begin{array}{l}22 \\
\text { (Ebay) }\end{array}$ & $\begin{array}{l}52 \\
\text { (Ebay) }\end{array}$ & $\begin{array}{l}14 \\
\text { (Amazon ) }\end{array}$ \\
\hline Battery pack mass $[\mathrm{kg}]$ & 0.19 & 0.35 & 1.9 \\
\hline
\end{tabular}


Battery. Table 1 shows the different battery technologies, which are compared in the simulation. The cell types ICR18650-26F and MP5-12C were chosen, because of their low cost and relative long cycle life. The type ANR26650M1-B was chosen, because it is a very advanced product in terms of cycle life.

The battery pack configuration was chosen to ensure, that the battery pack stores enough energy for 12 hours fishing even when it degrades after cycling. The minimal battery pack capacity is:

$$
C_{\min }=12 h \cdot \frac{\Phi}{U_{N} \cdot \eta_{L E D} \cdot \eta_{e l}}
$$

The minimal capacity is 7.6Ah for the Lithium-Ion battery, 8.5Ah for the Lithium-IronPhosphate battery and 2.34Ah for the 12V Lead-Acid battery.

Battery Model. The Battery Model was a voltage source with a serial resistor value correspondent to Table 1. The rise of the value of the serial resistor during the cycle life was neglected, because the voltage loss at the serial resistor is very low: The serial resistor value of the $4 \mathrm{p}$ Lithium-Ion battery pack is $25 \mathrm{~m} \Omega$. At the typical battery current of $0.7 \mathrm{~A}$ the voltage loss has a value of only $17.5 \mathrm{mV}$. The open circuit voltage of the battery was generated as a function of the battery SoC (State of Charge). The input data for this function were the characteristic discharge curves at low current $[5,6]$ and our measurements at the ICR18650-26F. We applied a model [7] for the capacity loss during the cycle life, which considered the DoD (Depth of Depletion), the average SoC and Temperature. We used the degradation coefficients for the A123 battery [7]. We computated the degradation coefficients for the Lithium-Ion and the Lead-Acid battery (Table 2).

Table 2: Assumptions for the computation of the degradation coefficients

\begin{tabular}{|l|l|l|}
\hline Cell type & ICR18650-26F & MP5-12C \\
\hline Cyle life 100\% DoD & $299[6]$ & $300[6]$ \\
\hline Cyle life 50\% DoD & $600[8]$ & $600[6]$ \\
\hline SoC & $\begin{array}{l}\text { Increase at degradation at high } \\
\text { SoC }>50 \%[7]\end{array}$ & $\begin{array}{l}\text { No increase of degradation at } \\
\text { high SoC }\end{array}$ \\
\hline Temperature & Doubling of degradation rate for each $10{ }^{\circ} \mathrm{C}$ rise in temperature \\
\hline
\end{tabular}

The influence of the calendar life was not implemented in the model, because the lifetime of the battery is mostly limited by the number of cycles and because no manufacturer data are available.

Simulation software. We wrote the simulation in MATLAB. It is a loop over the days of the simulation time. The battery is charged during the days, beginning at sunrise.

The battery is discharged in the fishing nights, beginning after sunset. The energy production of the solar module is calculated from to the irradiation value, supplied by Meteonorm. The software generates random fishing nights with fishing times corresponding to the behavior of the fishermen.

At the end of every fishing night, the software tests, if the fishing light worked as long as the fishermen fishing night was. The end of life of the battery is reached, when this was no more possible because of the degradation of the battery capacity. In such a case we assumed, that the fishermen replace the battery.

\section{Results}

Fig. 2 shows that the lifetime of the Lithium-Ion-Battery is about 600 days: Before this time, the working time of the fishing light is mostly equal to the length of the fishing light. Only at 2 days the working time is lower because of low irradiation at the day. After 600 days the capacity of the battery is too low for the length of the fishing night.

The battery pack has to be replaced after its lifetime. Table 3 shows the lifetime for the different cell types and battery technologies and the resulting cost per year and battery waste mass per year. 


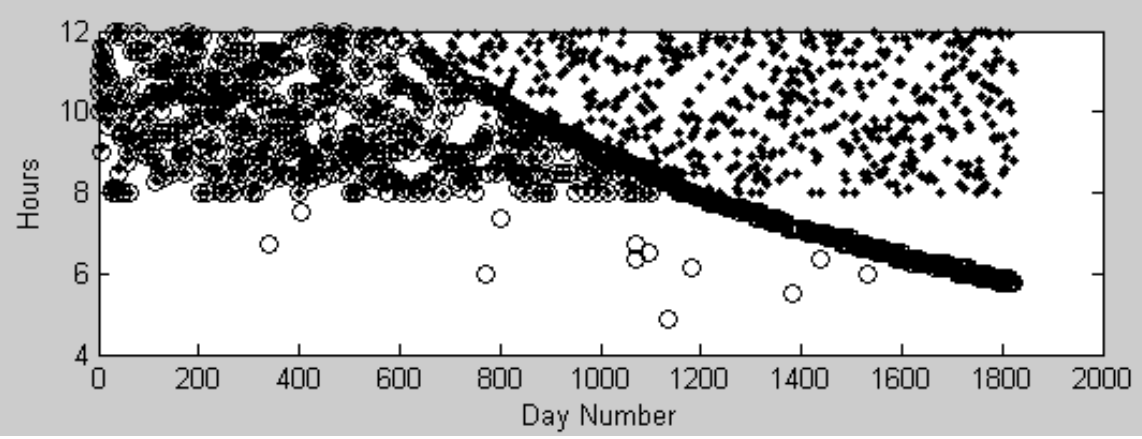

Figure 2: Length of the fishing night (square) and working time of the fishing light (circle) simulated for the Lithium-Ion battery pack.

Table 3: Lifetime, battery cost an waste mass per year.

\begin{tabular}{|l|l|l|l|}
\hline Cell Type & $\begin{array}{l}\text { ICR18650-26F } \\
\text { (Lithium-Ion) }\end{array}$ & $\begin{array}{l}\text { ANR26650M1-B } \\
\text { (Lithium-Iron-Phosphate) }\end{array}$ & $\begin{array}{l}\text { MP5-12C } \\
\text { (Sealed Lead-Acid) }\end{array}$ \\
\hline Lifetime [days] & 600 & 10000 & 1300 \\
\hline Battery cost per year [€] & 13.4 & 1.9 & 3.9 \\
\hline $\begin{array}{l}\text { Battery waste mass per year } \\
{[\mathrm{kg}]}\end{array}$ & 0.12 & 0.013 & 0.53 \\
\hline
\end{tabular}

\section{Summary}

The simulation (Table 3) shows, that the Lithium-Iron-Phosphate technology has a lifetime of 10000 days, which is by far longer than the lifetime of Sealed Lead-Acid technology (1300 days) and the Lithium-Ion technology (600 days). As a result, it has the lowest average cost and waste mass per year.

In future the accuracy of the simulation can be enhanced by cycling batteries with the current values, calculated by the simulation software. The results of the study can be used to motivate development aid to make the large scale application of solar power fishing lights possible.

\section{References}

[1] E. Mills, T. Gengnagel and P. Wollburg, Solar-LED alternatives to fuel-based Lighting for night fishing, Energy for Sustainable Development 21 (2014) 30-41.

[2] R. Aitken, A. Scholle, Night fishing with solar powered LED lights on Lake Tanganyika, paper presented at Innovating Energy Access for Remote Areas: Discovering Untapped Resources, UC Berkeley, April 10 - 12, 2014.

[3] M. P. McHenry, D. Doepel D, B. O. Onyango and U. L. Opara UL. Small-scale portable photovoltaic-battery-LED systems with submersible LED units to replace kerosene-based artisanal fishing lamps for sub-Saharan African lakes. Renew Energy 2014; 62:276-84.

[4] OmniVoltaic web site, Catch ${ }^{\mathrm{TM}} 300$ Specifications, http://www.omnivoltaic.com, 2014.

[5] A. Jossen, W. Weydanz, Moderne Akkumulatoren richtig einsetzen, Leipheim und München, 2006, pp. 39.

[6] Datasheets on the web sites of Samsung, Multipower and A123.

[7] A. Millner, Modeling Lithium Ion battery degradation in electric vehicles, Conference Publication, IEEE Conference on Innovative Technologies for an Efficient and Reliable Electricity Supply (CITRES), 2010.

[8] Battery University website, BU-808: How to Prolong Lithium-based Batteries, http://www.batteryuniversity.com, 2010. 